\title{
The Lexiconography of Toxicology
}

\author{
Kevin C. Osterhoudt, MD, MSCE, FACMTa
}

a The Poison Control Center and The Children's Hospital of Philadelphia, Philadelphia, PA

Always note and record the unusual... When you have made and recorded the unusual or original observation ... publish it. Place it on permanent record ... Such communications are always of value.

-Sir William Osler [1]

As Osler suggests, medical publishing began as a collection of clinical observations that allowed health care providers to communicate with one another and to learn from the experiences of other clinicians. The compilation of observational data and the dissemination of that data, in the manner of case reporting, remain an integral tool for the American Association of Poison Control Center's (AAPCC's) Toxic Exposure Surveillance System (TESS) as well as for practicing medical toxicologists [2]. In the current medical culture of "evidence-based medicine," effective communication of the results of analytical studies and experimental trials is a vital mission. The training routes for clinical certification of medical toxicologists via the Medical Toxicology Sub-Board (accredited by the American Council for Graduate Medical Education), of non-physician clinical toxicologists via the American Board of Applied Toxicology, and of Specialists in Poison Information via the American Association of Poison Control Centers admirably prepare health care providers for the art and science of clinical toxicology. But the semantics of toxicology-the linguistic foundation for effective communication and, subsequently, the advancement of medical toxicologyseem to remain muddled. Attention to the way we define and describe our medical specialty should be an important priority.

All things are poison and not without poison, only the dose makes a thing not a poison.

-Paracelsus (1493-1541)

In its report, "Forging a Poison Prevention and Control System," the Institute of Medicine quoted Paracelsus to highlight the etymological dilemma when attempting to develop an operational definition of "poisoning" [3]. They settled on a working definition for poisoning adapted from the United States Centers for Disease Control and Prevention; poisoning is defined as the "damaging physiological effects of ingestion, inhalation, or other exposure to a range of pharmaceuticals, illicit drugs, and chemicals, including pesticides, heavy metals, gases/vapors, and common household substances, such as bleach and ammonia." Defining poisoning is essential when trying to develop statistical and epidemiological analyses upon which to base decisions that effect the allocation of health care resources. Most would agree that death from an acute overdose of a cyclic antidepressant should classify as a poisoning death. But what about the mortality associated with cigarette smoking, or alcohol-related car crashes? What about the patient who dies from a relatively common complication of chemotherapy? The definition's traditional boundaries begin to blur.

Webster's unabridged dictionary defines a poison as "a substance (as a drug) that in suitable quantities has properties harmful or fatal to an organism when it is brought into contact with or absorbed by the organism" [4]. So, poisoning is "the abnormal condition produced by a poison or a toxic substance." A popular text of clinical toxicology simply states: "To poison means to injure or kill with poison, a chemical substance that usually kills, injures, or impairs an organism" [5]. Therefore, by convention, an exposure to a toxic agent or a drug overdose only becomes a poisoning when a physiologic derangement occurs.

When editing clinical and scientific toxicology manuscripts, "toxin" presents itself as another poorly understood word. Environmental lead would certainly classify as a poison. But is it a toxin? Dorland's medical dictionary has defined toxin as "a poison" that is "frequently used to refer specifically to a protein produced by some higher plants, certain animals, and pathogenic bacteria, which is highly toxic for other living organisms" [6]. Webster's defines a toxin as "any of various poisonous substances that are specific products of the metabolic activities of living organisms, are colloidal substances related to proteins and usu. very unstable, are notably toxic when introduced into the tissues but

Keywords: semantics, accidents, poisoning

Corresponding Author: Dr. Kevin Osterhoudt, The Poison Control Center, The Children's Hospital of Philadelphia, 34th Street and Civic Center Boulevard, Philadelphia, PA 19104. Email: OsterhoudtK@email.chop.edu 
are almost all destroyed by the digestive juices, and are typically capable of inducing antibody formation in suitable animals." In this journal authors are encouraged to consider the specific use of the word "toxin" to describe biologically derived poisons. In our discipline, the overlap between toxinology and toxicology remain somewhat controversial; but most toxicology textbooks include snake and arthropod envenomation and food poisoning syndromes within their realm [7].

In scientific writings describing the toxinology of snakebites, the words "poisonous" and "venomous" are often used interchangeably. Webster's dictionary defines venom as "poisonous matter normally secreted by some animals used chiefly in the taking of prey and in defense and communicated chiefly by biting or stinging." Dorland's medical dictionary describes envenomation as "poisoning by venom." Although it seems comfortable to call the toxic effects of a pit viper bite a poisoning, authors are encouraged to specifically use the terms "venomous" or "envenomation" when writing about poisonous animal bites and stings. Antivenom remains the preferred term for antibodies (or antibody fragments) against snake venoms purified for human use, a nomenclature made more confusing by the Wyeth Laboratories choice to name its antivenom "Antivenin (Crotalidae) Polyvalent."

Intoxication is another troubled word in the lexicon of toxicology. Webster's defines intoxication as "poisoning or the abnormal state induced by a chemical agent." Dorland's invokes the preferred conventional requirement of central nervous system alteration in its definition of intoxication as the "stimulation, excitement, or stupefaction produced by a chemical substance." Inebriation is "to intoxicate with alcohol." As a toxicology journal, the Journal of Medical Toxicology would prefer to classify alcohols as any compound with a hydrogenated oxygen group attached to a single bonded hydrocarbon, and we request that manuscripts be specific when detailing ethanol toxicology.

Consistent and accurate description of the epidemiology of poisoning also remains problematic within medical journals. An "ingestion" implies the act of swallowing a substance. An "overdose," by ingestion, implies the act of swallowing a greater dose than had been desired, or greater than that suggested by therapeutic guidelines. An ingestion or overdose only becomes a poisoning when it results in potentially harmful physiologic derangement. In its annual report, the AAPCC's TESS classifies the exploratory exposures of young children to potential poisons as "unintentional" [8]. Such a classification is not entirely accurate, since many inquisitive children do intend to ingest the interesting drugs and chemicals they encounter in their environment. However, they consume without the realization that such an act is potentially harmful. Any child exposed in such a manner may be classified as an exploratory exposure; a child poisoned in such a manner could-presumably-be classified as an "unintentional poisoning."

It has also been common toxicological vernacular to describe ingestions without intent of self-harm as "accidents." At least eleven poster presentations at the North American Congress of
Clinical Toxicology, Orlando, Florida, 2005, used the words "accident" or "accidental" as descriptors in such instances. Poisoning might be considered an accident if one Webster's definition is applied ("a usu. sudden event or change occurring without intent or volition through carelessness, unawareness, ignorance, or a combination of causes and producing an unfortunate result"), but it should not be considered an accident by another definition ("an event or condition occurring by chance or arising from unknown or remote causes"). To the extent that most pediatric poisoning is entirely preventable by reducing known risk factors, it should not be regarded as accidental by the conventions of this journal. Of note, the British Journal of Medicine has banned the "A" word as a descriptor for pediatric poisoning since 2001 [9]. In addition, the journal Clinical Toxicology has published two editorials admonishing the use of the word "accident" in most toxicology communications $[10,11]$.

The Institute of Medicine has declared poisoning the second leading cause of injury-related death in the United States [3]. Medical toxicologists strive to advance the science of medical toxicology to reduce poisoning morbidity and mortality. Proper classification of poisoning will enhance the ability to target areas of need, and proper definitions will allow effective communication between individual toxicologists acting as one team with a united goal. In our complex world we attempt to control our environment, improve our behavior, and advance medical care towards the primary, secondary, and tertiary prevention of poisoning injury. Perhaps "National Poison Prevention Week" should preferentially be proclaimed "National Poisoning Prevention Week" [12].

\section{REFERENCES}

1. Thayer WS. Osler, the teacher. Bulletin of the Johns Hopkins Hospital 1919; 30: 198-200.

2. Osterhoudt KC. Principles of epidemiology and research design. In: Goldfrank LR, Flomenbaum NE, Lewin NA, Howland MA, Hoffman RS, Nelson LS, editors. Goldfrank's Toxicologic Emergencies (7th ed.). New York: McGraw-Hill; 2002. pp. 1789-1797.

3. Institute of Medicine. Forging a Poison Prevention and Control System. Washington, D.C.: The National Academies Press; 2004. pp.27-79.

4. Gove PB. Webster's Third New International Dictionary of the English Language, Unabridged. Springfield, MA: MerriamWebster, Inc; 2002.

5. Shannon MW, Haddad LM. The emergency management of poisoning. In: Haddad LM, Shannon MW, Winchester JF, editors. Clinical Management of Poisoning and Drug Overdose (3rd ed.). Philadelphia: W.B. Saunders Company; 1998. pp. 2-31.

6. Anderson DM, Novak PD, Jefferson Keith MA, Elliot MA. Dorland's Illustrated Medical Dictionary (30th ed.). Philadelphia: W.B. Saunders Company; 2003. 
7. White J, Warrell D, Eddleston M, Currie BJ, Whyte IM, Isbister GK. Clinical toxinology-where are we now? J Toxicol Clin Toxicol 2003; 41: 263-276.

8. Watson WA, Litovitz TL, Rodgers GC, Klein-Schwartz W, Reid N, Youniss J, et al. 2004 annual report of the American association of poison control centers toxic exposure surveillance system. Am J Emerg Med 2005; 23: 589-666.

9. Davis RM, Pless B. BMJ bans “accidents." Br Med J 2001; 322: $1320-1321$.
10. Hung OL, Hoffman RS, Goldfrank LR. How dangerous is the unintentional use of the word accident in our literature? Clin Toxicol 1998; 36: 1-2.

11. Osterhoudt KC. Unintentional confusion of semantics is not accidental [letter]. J Toxicol Clin Toxicol 2003; 41: 207.

12. Bush GW. National poison prevention week proclamation. The White House [webpage on the Internet]. Washington, DC [updated 2005 Mar 18; cited 2005 Nov 7]. Available from: http:// www.whitehouse.gov/news/releases/2005/03/20050318-8.html 